\title{
Staphylococcal proliferation and biofilm formation in vitro under the influence of cell-free extracts of probiotic origin
}

\author{
0. V. Knysh ${ }^{\star A-D}$, O. Yu. Isaienko ${ }^{E, F}$, Ye. M. Babych ${ }^{E, F}, M$. M. Popov ${ }^{E, F}$
}

State Institution "Mechnikov Institute of Microbiology and Immunology of National Academy of Medical Sciences of Ukraine”, Kharkiv

A - research concept and design; B - collection and/or assembly of data; C - data analysis and interpretation; D - writing the article;

$\mathrm{E}$ - critical revision of the article; $\mathrm{F}$ - final approval of the article

Key words: cell-free system, cell proliferation, biofilm, probiotic, Bifidobacterium bifidum,

Lactobacillus

reuteri,

Staphylococcus

aureus,

Staphylococcus

epidermidis.

\section{Zaporozhye} medical journal 2019; 21 (4), 504-510

DOI:

10.14739/2310-1210.

2019.4.173350

*E-mail:

knysh_oksana@ukr.net
The paper presents the results of the study on proliferation and biofilm formation by Staphylococcus aureus and Staphylococcus epidermidis under the influence of cell-free extracts obtained by the author's method and containing derivatives of probiotic strains Bifidobacterium bifidum and Lactobacillus reuteri.

The aim of this work was to study the ability of cell-free extracts containing derivatives of probiotics Bifidobacterium bifidum and Lactobacillus reuteri to influence proliferation and biofilm formation by staphylococci in vitro, to evaluate the prospects of their use for the correction of microecological disorders and adjuvant therapy of staphylococcal infection.

Materials and methods. Cell-free extracts were obtained from commercial strains $B$. bifidum and $L$. reuteri by the authors' method. Reference strain of S. aureus ATCC 25923 and clinical isolate of S. epidermidis were used as a test cultures. The investigation of the proliferation and biofilm formation by staphylococci was carried out by spectrophotometric method using a microtiter-plate reader "Lisa Scan EM" (Erba Lachema s.r.o., Czech Republic).

Results. It has been established that the effect of cell-free extract on proliferation and biofilm formation depends on the type of extract and on the species of staphylococcus. Among the five studied extracts, only one significantly inhibits the proliferation and biofilm formation of both staphylococci species. It is the cell-free extract, obtained from $L$. reuteri culture, grown in its own disintegrate supplemented with glycerol and glucose. The proliferative activity of $S$. aureus is sensitive to the $L$. reuteri derivatives while the proliferative activity of $S$. epidermidis is sensitive to the $B$. bifidum derivatives. The filtrates of disintegrates have stimulatory effect, while the filtrates of cultures have inhibitory effect on the staphylococcal proliferation. The biofilm formation by $S$. aureus is significantly inhibited by $B$. bifidum derivatives and is stimulated by $L$. reuteri derivatives. The biofilm formation by $S$. epidermidis is stimulated by derivatives of bifidobacteria and does not change in the presence of derivatives of lactobacteria in the growth medium.

Conclusions. Obtained results indicate a high bioregulatory potential of cell-free extracts of probiotic origin and the possibility of drugs development for microecological disorders correction on their basis. They also confirm that the method of obtaining probiotic derivatives with bacteriotropic activity through precursor-directed biosynthesis is promising. Cell-free extract, obtained from L. reuteri culture, grown in its own disintegrate supplemented with glycerol and glucose, exhibits pronounced anti-staphylococcal activity in vitro. After confirming efficacy in vivo, it can be recommended for the adjuvant therapy of staphylococcal infections.
Киючові слова:

безклітинні

екстракти, пролі-

ферація, біоплів-

коутворення,

Аеривати пробіо-

тиків, Bifidobacterium

bifidum,

Lactobacillus

reuteri,

Staphylococcus

aureus,

Staphylococcus

epidermidis.

Запорізький

медичний

журнал. - 2019. -

T. 21, № 4(115). -

C. 504-510

\section{Проліферація та біоплівкоутворення стафілококів in vitro під впливом безкиітинних екстрактів пробіотичного походження}

\section{О. В. Книш, О. Ю. Ісаєнко, Є. М. Бабич, М. М. Попов}

Мета роботи - дослідити здатність безклітинних екстрактів, що містять деривати пробіотиків Bifidobacterium bifidum і Lactobacillus reuteri, впливати на проліфрерацію, біоплівкоутворення стафілококів in vitro, оцінити перспективність їхнього застосування для корекції мікроекологічних порушень та ад'ювантної терапії стафілококових інфекцій.

Матеріали та методи. Безклітинні екстракти отримували з комерційних штамів B. bifidum i L. reuteri за розробленим авторами методом. Як тестові культури використовували референс-штам S. aureus ATCC 25923 і клінічний ізолят S. epidermidis. Проліферацію, біоплівкоутворення стафілококів досліджували спектрофотометричним методом, використовуючи мікропланшетний аналізатор «Lisa Scan EM» («Erba Lachema s.r.o.», Чеська Республіка).

Результати. Встановили, що ефект безклітинного екстракту на проліферацію та біоплівкоутворення залежить від виду екстракту й виду стафілокока. Серед 5 екстрактів, котрі дослідили, тільки один істотно пригнічує проліферацію та біоплівкоутворення обох видів стафілококів. Це безклітинний екстракт, що отриманий із культури L. reuteri, яка вирощена у власному дезінтеграті з додаванням гліцерину, глюкози. Проліферативна активність $S$. aureus чутлива до впливу похідних L. reuteri, а проліферативна активність S. epidermidis - до впливу похідних B. bifidum. Фільтрати дезінтегратів мають стимуляторну, а фрільтрати культур - інгібіторну дію на проліферацію стафілококів. Біоплівкоутворення $S$. aureus суттєво пригнічується під дією дериватів B. bifidum і посилюється під впливом дериватів L. reuteri. Біоплівкоутворення S. epidermidis стимулюється дериватами біфідобактерій і не змінюється за наявності в ростовому середовищі дериватів лактобактерій.

Висновки. Результати свідчать про високий біорегуляторний потенціал безклітинних екстрактів пробіотичного походження та можливість створення на їхній основі препаратів для корекції мікроекологічних порушень. Вони також підтверджують перспективність методу одержання дериватів пробіотиків із бактеріотропною активністю шляхом керованого прекурсорами біосинтезу. Безклітинний екстракт, отриманий з культури L. reuteri, яка вирощена у власному дезінтеграті з додаванням гліцерину та глюкози, продемонстрував виражену протистафілококову активність in vitro. Після підтвердження ефективності in vivo він може бути рекомендований для ад'ювантної терапії стафілококових інфеекцій. 


\section{Пролиферация и биопленкообразование стафилококков in vitro под влиянием бесклеточных экстрактов пробиотического происхождения}

\section{О. В. Кныш, Е. Ю. Исаенко, Е. М. Бабич, Н. Н. Попов}

Цель работы - исследовать способность бесклеточных экстрактов, содержащих дериваты пробиотиков Bifidobacterium bifidum и Lactobacillus reuteri, влиять на пролиферацию и биопленкообразование стафилококков in vitro, оценить перспективность их применения для коррекции микроэкологических нарушений и адъювантной терапии стафилококковых инфекций.

Материалы и методы. Бесклеточные экстракты получали из коммерческих штаммов B. bifidum и L. reuteri разработанным авторами методом. В качестве тестовых культур использовали референс-штамм S. aureus ATCC 25923 и клинический изолят S. epidermidis. Исследование пролиферации и биопленкообразования стафилококков проводили спектрофоотометрическим методом с использованием микропланшетного анализатора «Lisa Scan EM» («Erba Lachema s.r.o.», Чешская Республика).

Результаты. Установлено, что эффект бесклеточного экстракта на пролиферацию и биопленкообразование зависит от вида экстракта и вида стафилококка. Среди исследованных 5 экстрактов только один значительно подавляет пролиферацию и биопленкообразование обоих видов стафилококков. Это бесклеточный экстракт, полученный из культуры L. reuteri, выращенной в собственном дезинтеграте с добавлением глицерина и глюкозы. Пролиферативная активность $S$. aureus чувствительна к воздействию производных L. reuteri, а пролиферативная активность S. epidermidis - к воздействию производных B. bifidum. Фильтраты дезинтегратов обладают стимулирующим, а фильтраты культур - угнетающим действием на пролиферацию стафилококков. Биопленкообразование S. aureus значительно подавляется под влиянием дериватов B. bifidum и усиливается под влиянием дериватов L. reuteri. Биопленкообразование S. epidermidis стимулируется дериватами бифидобактерий и не изменяется в присутствии дериватов лактобактерий в ростовой среде.

Выводы. Результаты свидетельствуют о высоком биорегуляторном потенциале бесклеточных экстрактов пробиотического происхождения и возможности создания на их основе препаратов для коррекции микроэкологических нарушений. Они также подтверждают перспективность метода получения дериватов пробиотиков с бактериотропной активностью путем управляемого прекурсорами биосинтеза. Бесклеточный экстракт, полученный из культуры L. reuteri, выращенной в собственном дезинтеграте с добавлением глицерина и глюкозы, продемонстрировал выраженную противостафилококковую активность in vitro. После подтверждения эфффективности in vivo он может быть рекомендован для адъювантной терапии стафилококковых инфекций.

Among the more than 70 species of the genus Staphylococcus, the most pathogenic for humans is Staphylococcus aureus. It persistently colonizes approximately $20 \%$ of the human adult population. The main biotopes that $S$. aureus colonizes: the anterior nares and skin. It is considered the main causative agent of nosocomial and community-acquired infections [1,2]. There are many known factors of $S$. aureus virulence and pathogenicity: degradative enzymes, pore-forming toxins, superantigens, immunostimulatory exo-proteins and others [3]. S. aureus can cause both acute and chronic infectious processes. Acute infections are generally caused by planktonic cells. In this case, the production of secreted toxins and exo-enzymes is the main pathogenicity factor. In contrast, chronic infections are associated with the ability of $S$. aureus to attach to host tissues or implanted medical devices, to form a biofilm and persist in this state for a long time [2-4].

Traditionally considered, that Staphylococcus epidermidis is a harmless commensal that lives on human skin. By preventing the attachment of pathogenic staphylococci, it provides colonization resistance of mucous membranes and skin. But $S$. epidermidis can cause an infectious process in newborns, immuno-compromised patients or patients undergoing surgery, with multiorgan pathology. The widespread use of medical devices has made $S$. epidermidis the most clinically important opportunistic agent that often causes nosocomial infections $[4,5]$. The main pathogenicity factor of $S$. epidermidis is the ability to biofilm formation $[5,6]$.

Today, quite a lot of work has been devoted to the study of biofilm formation by bacteria of $S$. aureus and $S$. epidermidis species [1-3,7]. Biofilm formation protects microbial cells from antimicrobial agents, the host's immune system and makes them more difficult to eliminate [2]. The resis- tance of bacteria in the composition of a biofilm can be in tens of thousands of times greater than the resistance of the same microorganisms in planktonic form [8]. In recent years, an active search for substances and compounds with anti-biofilm activity has been conducted. It was found out that cationic antimicrobial peptides varnerin and hominin can not only prevent biofilm formation by coagulase-negative staphylococci, but also actively destroy the formed biofilm [9]. Bacteriocins also had an inhibitory effect on biofilm formation in vitro [10]. It has been shown that enzymes can have different effects on biofilm formation: while DNAse can inhibit, a-galactosidase can stimulate this process [11]. The enzyme oligoribonuclease effectively suppresses the exchange of chemical signals between individual bacterial cells. It can be used to stop or prevent the biofilm formation by bacteria [8].

The development of new effective drugs with antimicrobial and anti-biofilm activity is one of the priorities of the modern pharmacological industry $[8,9,17]$. The ability of some species of staphylococci to inhibit biofilm formation and destroy the biofilms formed by other species of staphylococci suggests the promise of finding effective regulators of this process among natural microbial antagonists [7]. Recently, in vitro studies and clinical trials have accumulated much evidence of the effect of probiotics on infectious agents through a competition and counteraction. However, data on the use of probiotics as tools to prevent the formation or destruction of preformed biofilms is not enough $[12,13,20,21]$. Considering the natural antagonism of probiotics in relation to conditionally pathogenic and pathogenic microorganisms, it seems logical to search for antimicrobial and anti-biofilm substances among probiotic derivatives.
Ключевые слова: бесклеточные экстракты, пролиферация, биопленкообразование, дериваты пробиотиков, Bifidobacterium bifidum, Lactobacillus reuteri, Staphylococcus aureus, Staphylococcus epidermidis.

Запорожский медицинский журнал. - 2019. T. 21, № 4(115). C. $504-510$ 


\section{The aim}

The aim of this work was to study the ability of cell-free extracts containing derivatives of probiotics Bifidobacterium bifidum and Lactobacillus reuteri to influence proliferation and biofilm formation by staphylococci in vitro, to evaluate the prospects of their use for the correction of microecological disorders and adjuvant therapy of staphylococcal infection.

\section{Materials and methods}

Two commercial probiotic strains were used as sources of biologically active structural components and as producers of metabolites. These were B. bifidum No 1 (from medical product "Bifidumbacterin-Biopharma", JSC "Biopharma", Ukraine) and L. reuteri DSM 17938 (from medical product "BioGaia", BioGaia AB, Sweden). Five types of cell-free extracts have been studied: $L-$ filtrate of $L$. reuteri disintegrate; $M L$ - filtrate of $L$. reuteri culture, grown in $L$. reuteri disintegrate; MLG - filtrate of $L$. reuteri culture, grown in L. reuteri disintegrate supplemented with $0,8 \mathrm{M}(73.7 \mathrm{~g} / \mathrm{l})$ glycerol and $0.4 \mathrm{M}(72.1 \mathrm{~g} / \mathrm{l})$ glucose; $\mathrm{B}$ - filtrate of $B$. bifidum disintegrate; $\mathrm{MB}$ - filtrate of $B$. bifidum culture, grown in B. bifidum disintegrate.

Test samples were obtained by the authors' method [14]. Disintegrates were obtained by physical method of disintegration. It was a multiple freezing-thawing of the microbial mass. To obtain the disintegrate, cell suspension in physiological saline with optical density of 10.0 units according to the McFarland scale measured using the Densi-La-Meter (PLIVA-Lachema, Czech Republic) was exposed to 10 cycles of freeze-thawing according to the following regimen: freezing - passive cooling in freezing chamber of Samsung RB29FSRNDSA refrigerator down to $-23 \pm 1{ }^{\circ} \mathrm{C}$, heating - in water bath at $37 \pm 1^{\circ} \mathrm{C}$ up to complete thawing.

Cultures were obtained by cultivating of probiotic microorganisms in their own disintegrates. To this end the probiotic suspension in physiological saline of turbidity 10.0 units on the McFarland scale was added into disintegrate in $1: 9$ ratio and cultured at $37 \pm 1^{\circ} \mathrm{C}$ for 72 hours in anaerobic conditions.

Disintegrates and probiotic cultures grown in their own disintegrates were centrifuged at $3000 \mathrm{~g}$ for 10 minutes in order to remove remained cells and cellular debris. Supernatant was passed through sterile membrane filters with pore diameter of 0.2 micron (Vladipor, Russian Federation).

Coagulase-positive reference strain S. aureus ATCC 25923 (from the Museum of Microorganisms of IMI NAMS, Kharkiv) and coagulase-negative clinical isolate S. epidermidis № 558 (from the Collection of Microorganisms of the Laboratory of Respiratory Infections Prevention of IMI NAMS, Kharkiv) were used as a test cultures. The test cultures were cultivated overnight aerobically at $37^{\circ} \mathrm{C}$ on appropriate solid nutrient medium. It was blood agar.

Preparation of the inoculum: after verifying the purity of the culture, few colonies from the overnight incubated agar medium were emulsified in a physiological saline for obtaining a suspension of turbidity 0.5 on the McFarland scale.
Assessment of biofilm formation by staphylococci. Staphylococcal biofilms were obtained in sterile 96-well polystyrene microtiter plates (JSC "Eximcargotrade", Ukraine) by modified S. Stepanovic's microtiter-plate technique [15]. The tryptone soya broth (TSB; HiMedia, India) supplemented with $1 \%$ glucose aseptically was added into all wells of the microtiter plate. Cell-free derivative-containing extracts were added into the test wells to achieve a final concentration $20 \%$ vol. Physiological saline was added to the positive control wells (PC) in the same volume. The inoculum was vortexed and then inoculated into a test and positive control wells of the microtiter plate. The final concentration of cells in the incubation medium was $\sim 10^{7} \mathrm{CFU} / \mathrm{ml}$. The negative control wells (NC) contained TSB supplemented with $1 \%$ glucose and physiological saline instead of cell-free extracts and inoculum. The plates were covered with lids and incubated aerobically for 24 hours at $35-37^{\circ} \mathrm{C}$ in static conditions. After incubation, the contents of the wells have been removed. Each well was washed three times with sterile $0.1 \mathrm{M}$ phosphate-buffered saline (PBS; pH 7.2). Remaining attached biofilms were fixed by exposing them to hot air at $60{ }^{\circ} \mathrm{C}$ for $60 \mathrm{~min}$; they were stained by $1 \%$ crystal violet for $15 \mathrm{~min}$. After that, wells were washed ten times with distilled water. Ethanol was gently added and thereafter the microtiter plate covered with the lid. It was left at room temperature for $30 \mathrm{~min}$. The optical density (OD) of the test and control wells was measured at $630 \mathrm{~nm}$ by using a microtiter-plate reader "Lisa Scan EM" (Erba Lachema s.r.o., Czech Republic). Based on the OD values obtained for $\mathrm{NC}$ and test samples, biofilm formation was defined as:

weak $\left(O D_{\mathrm{NC}}<\mathrm{OD} \leq 2 \times \mathrm{XD}_{\mathrm{NC}}\right)$;

moderate $\left(2 \mathrm{xOD}_{\mathrm{NC}}<\mathrm{OD} \leq 4 \times \mathrm{XD}_{\mathrm{NC}}\right)$;

strong $\left(4 \mathrm{xOD}_{\mathrm{NC}}<\mathrm{OD}\right)$;

no biofilm formation $\left(O D \leq O D_{N C}\right)$, according to $\ln$ Lee S. et al. [16].

The inhibition (or stimulation) index was calculated by the formula: Inhl $(S t)=\left(O D-O D_{P C}\right) \div O D_{P C} \times 100 \%$, where $\mathrm{OD}_{\mathrm{PC}}$ and $\mathrm{OD}$ were optical density of the control and test samples, respectively.

Assessment of staphylococcal proliferation. The study of the effect of cell-free extracts on the proliferation of staphylococci was performed by modified Gladisheva's method [17]. Cell-free extracts and diluted 10 times inoculums were added into the test wells in the ratio of 9:1. Physiological saline and inoculums were added into the positive control wells $(\mathrm{PC})$ in the same ratio. The negative control wells (NC) contained only physiological saline. The plates were covered with lids and incubated aerobically for 1 hour at $35-37{ }^{\circ} \mathrm{C}$ in static conditions. After incubation, pepted meat broth (PMB; HiMedia, India) supplemented with $1 \%$ glucose aseptically was added into all wells of the microtiter plate in volume exceeding the total volume of cell-free extract and inoculum by 2 times. The final concentration of microbial cells in the incubation medium was $\sim 10^{5} \mathrm{CFU} / \mathrm{ml}$. The optical density (OD) of the wells was measured at $578 \mathrm{~nm}$ using a microtiter-plate reader "Lisa Scan EM' (Erba Lachema s.r.o., Czech Republic) immediately after adding PMB and after incubation of plates aerobically for 24 hours at $35-37^{\circ} \mathrm{C}$ in static conditions. The inhibition (or stimulation) index was calculated by the formula: Inhl $(\mathrm{Stl})=\left(\Delta \mathrm{OD}-\Delta O \mathrm{D}_{\mathrm{PC}}\right) \div \Delta O \mathrm{D}_{\mathrm{PC}} \times 100 \%$, where $\Delta \mathrm{OD}$ and 


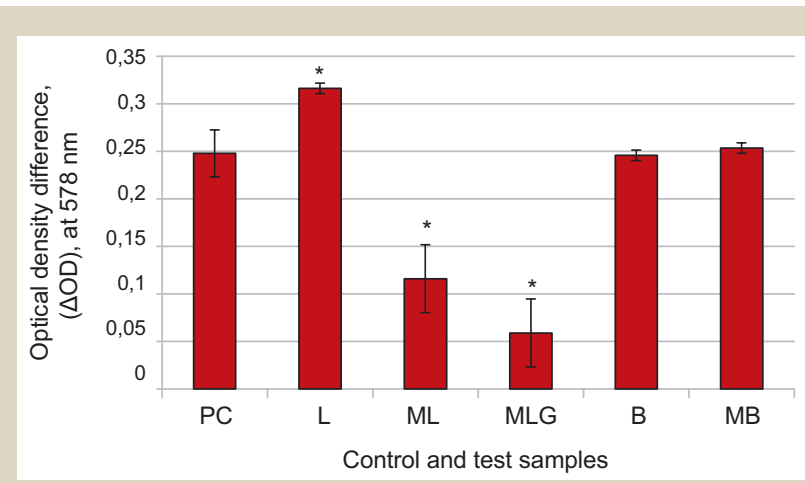

Fig. 1. The effect of cell-free extracts on the proliferation of $S$. aureus. Data are presented as average $\triangle O D$ (optical density changes within 24 hours) of the test and control samples.

*: the differences are significant compared to the positive control sample (PC), $P<0.05$.

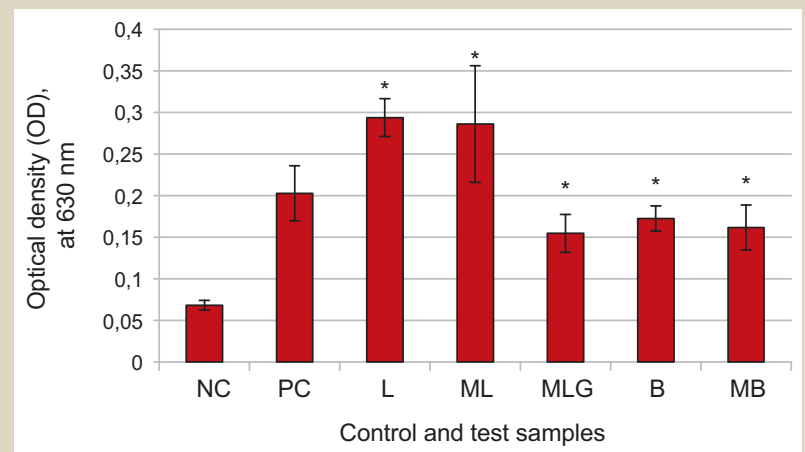

Fig. 3. The effect of cell-free extracts on the biofilm formation by S. aureus. Data are presented as average OD of the test and control samples.

*: the differences are significant compared to the positive control sample $(\mathrm{PC}), \mathrm{P}<0.05$.

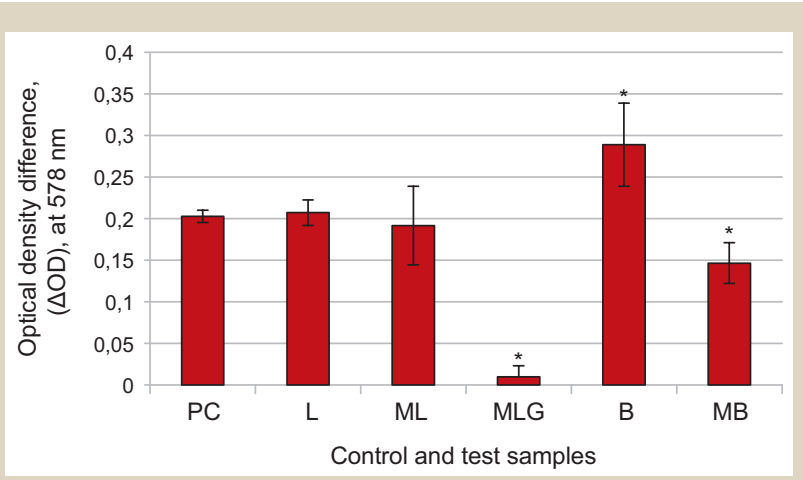

Fig. 2. The effect of cell-free extracts on the proliferation of S. epidermidis. Data are presented as average $\triangle O D$ (optical density changes within 24 hours) of the test and control samples.

*: the differences are significant compared to the positive control sample $(\mathrm{PC}), \mathrm{P}<0.05$

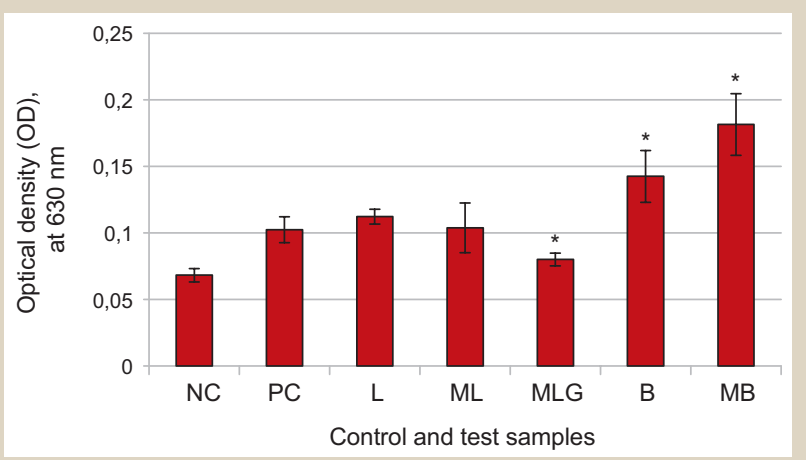

Fig. 4. The effect of cell-free extracts on the biofilm formation by S. epidermidis. Data are presented as average OD of the test and control samples.

*: the differences are significant compared to the positive control sample (PC), $\mathrm{P}<0.05$
$\Delta O D_{P C}$ were the changes in the optical density of the control and test samples within 24 hours.

All experiments were performed three times. Each sample was tested in triplicate. Obtained data were statistically processed with Excel 2010 software (Microsoft, USA). Average values of obtained indices with standard deviations were determined. The significance of the difference between the obtained indices of the test and control groups was determined by Student's t-test. Differences were considered significant at $P<0.05$.

\section{Results}

As shown in Fig. 1, extract $L$ had a significant stimulatory effect on proliferation of $S$. aureus (StI $-27.6 \%, P<0.04$ ). Pronounced inhibition of staphylococcal proliferation was observed under the influence of extracts $M L$ (Inhl $-53.2 \%$, $P<0.009)$ and $M L G(\operatorname{lnhl}-76.2 \%, P<0.003)$. Taking into account Inhl, the filtrate of $L$. reuteri culture, grown in $L$. reuteri disintegrate supplemented with glycerol and glucose (MLG), causes more pronounced inhibition of $S$. aureus proliferation, than filtrate of $L$. reuteri culture grown in its own disintegrate without additives (ML). Extracts $B$ and $M B$ had no significant effect on the proliferation of this test culture.

Fig. 2 shows, that extract $B$ exerted a significant stimulatory effect on the proliferation of $S$. epidermidis (Stl $-42.5 \%, P<0.03)$. Introduction into the growth medium of $M L G$ and $M B$ extracts resulted in inhibition of staphylococcal proliferation by $95.2 \%(\mathrm{P}<0.0002)$ and $27.7 \%(\mathrm{P}<0.05)$, respectively. It should be noted that $M L G$ filtrate, obtained from $L$. reuteri culture, grown in $L$. reuteri disintegrate supplemented with glycerol and glucose, has a significantly more pronounced inhibitory effect on the proliferation of $S$. epidermidis than $M B$ extract, obtained from $B$. bifidum culture, grown in $B$. bifidum disintegrate. Extracts $L$ and $M L$ did not affect proliferative activity of $S$. epidermidis.

Fig. 3 shows the ability of the $S$. aureus to produce biofilm in the polystyrene microplate. Based on a comparison of the mean value $O D_{\mathrm{PC}}$ with the mean value of $O D_{\mathrm{NC}}$, the culture was classified as moderate biofilm-producer. A significant stimulation of biofilm formation by this culture occurred under the influence of extracts $L$ and $M L$. Stl were $44.8 \%$ $(P<0.00001)$ and $41 \%(P<0.009)$, respectively. Extracts $M L G, B, M B$ in the growth medium, on the contrary, inhibited biofilm formation by $S$. aureus. Inhl were $23.7 \%(P \leq 0.003)$; $15 \%(P<0.03)$ and $20.3 \%(P<0.02)$, respectively.

S. epidermidis showed weak ability to produce biofilms on polystyrene microplates within 24 hours (Fig. 4). Introduction into the growth medium of $L$ and $M L$ extracts did not have a significant effect on the biofilm formation by this test-culture. The presence in the growth medium of extract $M L G$ resulted in a significant inhibition of biofilm formation by staphylococcus, the Inhl was $21.8 \%(P<0.00006)$. Cell-free extracts, containing derivatives of $B$. bifidum $(B$ and $M B)$, had a powerful stimulating effect on biofilm formation by S. epidermidis. Stl were $43.7 \%(P<0.0002)$ and $77.2 \%$ $(P<0.000002)$, respectively. 


\section{Discussion}

In the work, the slow disintegration by the freezing-warming method was used. This method does not provide for the rapid and complete destruction of bacterial cells to obtain a set of structural components. A distinctive feature of this method is the creation of shock conditions for microbial cells. They are exposed to thermal, osmotic, thermomechanical, dehydration and rehydration shock. In created conditions under the influence of a complex of damaging factors there are sublethal, lethal injuries and diversity of metabolic changes in response to stress occur in cells. Bacteria specifically respond to an abrupt decrease in temperature. The cold shock response (CSR) is a cascade of cellular reactions, accompanied by a high level of temporarily expression of cold-induced proteins (CIPs). CIPs have pleiotropic functions, such as the regulation of transcription, translation, and splicing. They have the ability to orchestrate multiple cellular processes, including proliferation and differentiation [18].

Thus, disintegrate obtained by repeated freezing-thawing of a bacterial suspension contains not only the structural components of bacterial cells (microbe-associated molecular patterns, MAMPs), but also bacterial cold shock proteins (damage-associated molecular patterns, DAMPs), which possess powerful bioregulatory potential. In addition, disintegrate also contains a set of substances suitable for nutrition of microorganisms. We used this property of disintegrate, applying it as a nutrient medium in the cultivation of probiotics.

It is known that a change in cultivation conditions has a significant effect on metabolic processes in microbial cells, and hence on the composition of metabolites. Live, growing, proliferating lactic acid bacteria release into the environment a large number of metabolites - organic acids, hydrogen peroxide, ethyl alcohol, bacteriocins, and other biologically active compounds. They have antimicrobial, antiviral, immunomodulatory, anti-inflammatory, antitumor and other types of activity. Cell-free filtrates have a complex composition. The directionality and intensity of the filtrates' effects on the biological processes are the result of the summation of its components effects. The determination of each component's effect is possible after fractionation of the cell-free filtrate. At present, we are studying the biochemical composition of disintegrates and cultures, grown in their own disintegrates. The content of some important biologically active components (protein, peptides, amino acids, nucleic acids, teichoic acids, etc.) has been determined. A separate article will be devoted to the coverage of the results.

The results of the experimental study demonstrate the different directionality of the effects of cell-free extracts, introduced into the growth medium, on proliferation and biofilm formation by staphylococci and revealed some regularity. The direction of the effect depends on the species of staphylococcus and the type of cell-free extract. Cell-free extracts have a different composition depending on the source and method of their obtaining. Extract $L$, containing products of disintegration of $L$. reuteri, stimulate proliferation and biofilm formation by $S$. aureus, but does not have a significant effect on proliferation and biofilm formation by $S$. epidermidis. Extract $B$, containing products of disintegration of $B$. bifidum, has a stimulatory effect on proliferation and biofilm formation by $S$. epidermidis. It does not have a significant effect on proliferation, but inhibits biofilm formation by $S$. aureus. Obtained results confirm the existence of a mechanism of influence on the ability to form biofilms, which does not involve growth inhibition $[7,19,20]$. Recent studies in this area demonstrate that inhibition of biofilm formation without affecting the growth is possible due to the inhibition of ica-operon expression by metabolites or lipoteichoic acid (LTA) of probiotics [19,20]. Ica-operon responsible for the production of poly-N-acetylglucosamine (a key molecule required for $S$. aureus biofilm development) $[19,20]$. Remarkably, whereas metabolites of $L$. fermentum inhibit the biofilm formation by $S$ aureus, metabolites of $L$. plantarum do not appear such ability [19]. LTA without D-alanine moieties do not inhibit biofilm formation by $S$. aureus [20].

The introduction into the growth medium of $M L$ extract, which contains products of disintegration and metabolic products of $L$. reuteri, leads to the inhibition of proliferation and stimulation of biofilm formation by $S$. aureus, but does not affect the indicated abilities of $S$. epidermidis. Inhibitory effect of $M L$ extract on proliferation can be explained by the antimicrobial activity of $L$. reuteri metabolites against $S$. aureus. The introduction into the growth medium of $M B$ extract, containing the products of disintegration and metabolic products of $B$. bifidum, causes inhibition of proliferation and stimulation of biofilm formation by S. epidermidis. It does not affect proliferation and inhibits biofilm formation by $S$. aureus. Inhibitory effect of MB extract on proliferation can be explained by the antimicrobial activity of $B$. bifidum metabolites against $S$. epidermidis. Our data is only partially consistent with the results of studies by other authors, who showed that exometabolites of B. bifidum had a pronounced inhibitory effect on the proliferative activity and biofilm formation of staphylococci [13]. The difference in the results indicates the importance of the method for obtaining probiotic derivatives, which predetermines the composition of the final product. Extract $M L G$ demonstrated a significant inhibitory effect on the proliferation and biofilm formation by both species of staphylococci. It contains products of disintegration and metabolic products of $L$. reuteri obtained by cultivation in its own disintegrate supplemented with glycerol and glucose. It is known that $L$. reuteri can convert glycerol into the antimicrobial compound reuterin [21]. We suggest that inhibitory effect of $M L G$ extract on the proliferation and biofilm formation by staphylococci is due to reuterin.

\section{Conclusions}

1. Obtained results have a practical importance. They indicate a high bioregulatory potential of cell-free extracts of probiotic origin and the possibility of drugs development for microecological disorders correction on their basis.

2. The results also confirm that the method of obtaining probiotics' derivatives with bacteriotropic activity through precursor-directed biosynthesis is promising.

3. Cell-free extract obtained from $L$. reuteri culture grown in its own disintegrate supplemented with glycerol and glucose, exhibits pronounced anti-staphylococcal activity in vitro. After confirming efficacy in vivo, it can be recommended for the adjuvant therapy of staphylococcal infections. 
Prospects for further research. Obtained results will be used in the planning and conducting further experimental studies towards the development of new metabiotics based on $B$. bifidum and $L$. reuteri derivatives.

\section{Funding}

The study is a fragment of the research project of the Laboratory of Respiratory Infections Prevention, State Institution "Mechnikov Institute of Microbiology and Immunology of National Academy of Medical Sciences of Ukraine", "Microbiological characteristic of new structural and metabolic complexes of lacto- and bifidoprobiotics" (State registration No. 0119U100686).

Conflicts of interest: authors have no conflict of interest to declare. Конфмікт інтересів: віАсутній.

Надійшка Ао редакції / Received: 29.10.2018

Після Аоопрацювання / Revised: 08.01.2019

Прийнято Ао Аруку / Accepted: 09.01.2019

Information about authors:

Knysh O. V., MD, PhD, Senior Researcher of the Laboratory of Respiratory Infections Prevention, State Institution "Mechnikov Institute of Microbiology and Immunology of National Academy of Medical Sciences of Ukraine", Kharkiv, Ukraine.

ORCID ID: 0000-0002-4105-1299

Isaienko 0. Yu., MD, PhD, Leading Researcher of the Laboratory of Respiratory Infections Prevention, State Institution "Mechnikov Institute of Microbiology and Immunology of National Academy of Medical Sciences of Ukraine", Kharkiv, Ukraine.

ORCID ID: 0000-0002-5575-1296

Babych Ye. M., MD, PhD, DSc, Professor, Head of the Laboratory of Respiratory Infections Prevention, State Institution "Mechnikov Institute of Microbiology and Immunology of National Academy of Medical Sciences of Ukraine", Kharkiv, Ukraine.

ORCID ID: 0000-0002-9382-584X

Popov M. M., MD, PhD, DSc, Professor, Director of State Institution "Mechnikov Institute of Microbiology and Immunology of National Academy of Medical Sciences of Ukraine", Kharkiv, Ukraine. ORCID ID: 0000-0002-6875-3071

\section{Відомості про авторів:}

Книш О. В., канА. меА. наук, ст. науковий співробітник лабораторії профілактики краплинних інфекцій, АУ „Інститут мікробіології та імунології імені І. І. Мечникова НАМН України", м. Харків.

Ісаєнко О. Ю., канА. меА. наук, провіАний науковий співробітник лабораторії профілактики краплинних інфекцій, АУ «нститут мікробіології та імунології імені І. І. Мечникова НАМН України", м. Харків.

Бабич Є. М., А-р меА. наук, професор, зав. лабораторії профілактики краплинних інфекцій, АУ «нститут мікробіології та імунології імені І. І. Мечникова НАМН України", м. Харків. Попов М. М., А-р меА. наук, професор, директор АУ «Інститут мікробіології та імунології імені І. І. Мечникова НАМН України", м. Харків.

\section{Сведения об авторах:}

Кныш О. В., канА. меА. наук, ст. научный сотрудник лаборатории профилактики капельных инфекций, ГУ «Институт микробиологии и иммунологии имени И. И. Мечникова НАМН Украины", г. Харьков.

Исаенко Е. Ю., канА. меА. наук, ведущий научный сотрудник лаборатории профилактики капельных инфекций, ГУ “Институт микробиологии и иммунологии имени И. И. Мечникова НАМН Украины", г. Харьков.

Бабич Е. М., А-р меА. наук, профессор, зав. лаборатории профилактики капельных инфекций, ГУ «Институт микробиологии и иммунологии имени И. И. Мечникова НАМН Украины", г. Харьков.
Попов Н. Н., А-р меА. наук, профессор, Аиректор ГУ «Институт микробиологии и иммунологии имени И. И. Мечникова НАМН Украины", г. Харьков.

\section{References}

[1] Kornienko, M. A., Kopyltsov, V. N., Ilina, E. N., Shevlyagina, N. V. Didenko, L. V., Lyubasovskaya, L. A., \& Priputnevich, T. V. (2016). Sposobnost' stafilokokkov razlichnykh vidov k obrazovaniyu bioplenok i ikh vozdejstvie na kletki cheloveka [The ability of various strains of Staphylococcus to create biofilms and their effect on cells of the human body]. Molekulyarnaya genetika, mikrobiologiya i virusologiya, 34(1), 18-25. [in Russian].

[2] Lister, J. L., \& Horswill, A. R. (2014). Staphylococcus aureus biofilms: recent developments in biofilm dispersal. Frontiers In Cellular And Infection Microbiology, 4, 178. doi: 10.3389/fcimb. 2014.00178

[3] Kavanaugh, J., \& Horswill, A. R. (2016). Impact of Environmental Cues on Staphylococcal Quorum Sensing and Biofilm Development. Journal of Biological Chemistry, 291(24), 12556-12564. doi: 10.1074/jbc.r116.722710

[4] Paharik, A. E, \& Horswill, A. R. (2016). The staphylococcal biofilm: adhesins, regulation, and host response. Microbiology Spectrum, 4(2). doi: 10.1128/microbiolspec.VMBF-0022-2015

[5] Becker, K., Heilmann, C., \& Peters, G. (2014). Coagulase-negative staphylococci. Clinical Microbiology Reviews, 27(4), 870-926. doi: $10.1128 / \mathrm{cmr} .00109-13$

[6] Otto, M. (2013). Staphylococcus epidermidis pathogenesis. Methods in Molecular Biology, 1106, 17-31. doi: 10.1007/978-1-62703-736-5_2

[7] Goetz, C., Tremblay, Y., Lamarche, D., Blondeau, A., Gaudreau, A. Labrie, J., et al. (2017). Coagulase-negative staphylococci species affect biofilm formation of other coagulase-negative and coagulasepositive staphylococci. Journal of Dairy Science, 100(8), 6454-6464. doi: 10.3168/jds.2017-12629

[8] Orr, M., Donaldson, G., Severin, G., Wang, J., Sintim, H., Waters, C., et al. (2015). Oligoribonuclease is the primary degradative enzyme for $\mathrm{pGpG}$ in Pseudomonas aeruginosa that is required for cyclic-di-GMP turnover. Proceedings of The National Academy of Sciences, 112(36), E5048-E5057. doi: 10.1073/pnas.1507245112

[9] Korobov, V. P., Lemkina, L. M., \& Polyudova, T. V. (2015). Destrukciya bioplenok koagulazonegativnykh stafilokokkov pod dejstviem bakterial'nykh kationnykh peptidov [Destruction biofilms of coagulase-negative staphylococci by bacterial cationic peptides]. Vestnik Permskogo universiteta. Seriya: Biologiya, 3, 233-239. [in Russian]

[10] Rybalchenko, O. V., Bondarenko, V. M., \& Orlova, O. G. (2013). Struktura i funktsii bakterial'nykh bioplenok simbioticheskikh i uslovno-patogennykh bakterii [Structure and functions of bacterial biofilms of symbiotic and opportunistic bacteria]. Verhnevolzhskij medicinskij zhurnal, 11(4), 37-42. [in Russian].

[11] Terenteva, N. A., Timchenko, N. F., \& Rasskazov, V. A. (2014). Issledovanie vliyaniya biologicheski aktivnykh veschestv na formirovanie bakterial'nykh bioplenok [Study of biological active substances on the bacterial biofilm formation]. Zdorov'e. Medicinskaya e'kologiya. Nauka, 3(57). 54-55. [in Russian].

[12] Vuotto, C., Longo, F., \& Donelli, G. (2014). Probiotics to counteract biofilm-associated infections: promising and conflicting data. International Journal of Oral Science, 6(4), 189-194. doi: 10.1038/ijos.2014.52

[13] Markov, A. A., Timokhina, T. Kh., Perunova, N. B., \& Paromova, Ya. I. (2018). Vozmozhnost' primeneniya e'kzometabolitov Bifidobacterium bifidum $v$ travmatologii i ortopedii dlya predotvrascheniya pervichnoj kontaminacii i bioplenkoobrazovaniya na poverkhnosti implantatov $s$ sinteticheskim bioaktivnym kalcij-fosfatnym mineral'nym pokryitiem [The possibility of using bifidobacterium bifidum exometabolites in traumatology and orthopedics to prevent primary contamination and biofilm formation on the surface of implants with synthetic bioactive calcium-phosphate mineral coating]. Medicinskij al'manakh, 3(54), 128-130. doi: 10.21145/2499-9954-2018-3-128-130 [in Russian].

[14] Knysh, O. V., Isaienko, O. Yu., Babych, Ye. M., Polianska, V. P., Zachepylo, S. V., Kompaniiets, A. M., Horbach, T. V. (2018). Patent Ukrainy 122859. МПК C12N 1/20, A61K 35/74, C12R 1/25. Sposib oderzhannia biolohichno aktyvnykh deryvativ bakterii probiotychnykh shtamiv [Patent of Ukraine 122859, MПК C12N 1/20, A61K 35/74, C12R $1 / 25$. Method for obtaining biologically active derivatives of probiotic strains bacteria]. Biuleten, 2. [in Ukrainian].

[15] Stepanović, S., Vuković, D., Hola, V., Bonaventura, G., Djukić, S. Ćirković, I., \& Ruzicka, F. (2007). Quantification of biofilm in microtiter plates: overview of testing conditions and practical recommendations for assessment of biofilm production by staphylococci. APMIS, 115(8) 891-899. doi: 10.1111/j.1600-0463.2007.apm 630.x

[16] In Lee, S., Barancelli, G., de Camargo, T. M., Corassin, C. H., Rosim, R. E., da Cruz, A., et al. (2017). Biofilm-producing ability of Listeria monocytogenes isolates from Brazilian cheese processing plants. Food Research International, 91, 88-91. doi: 10.1016/j.foodres.2016.11.039 
[17] Gladysheva, I. V. (2014). Antagonisticheskaya aktivnost' korinebakterij [Antagonistic activity of corynebacteria]. Vestnik Orenburgskogo gosudarstvennogo universiteta, 13(174), 16-19. [in Russian].

[18] Lindquist, J. A., \& Mertens, P. R. (2018). Cold shock proteins: from cellular mechanisms to pathophysiology and disease. Cell Communication and Signaling, 16(1), 63. doi: 10.1186/s12964-018-0274-6

[19] Melo, T. A., dos Santos, T. F., de Almeida, M. E., Junior, L. A., G. F., Andrade, E. F., Rezende, R. P., et al. (2016). Inhibition of Staphylococcus aureus biofilm by Lactobacillus isolated from fine cocoa. BMC microbiology, 16, 250. doi: 10.1186/s12866-016-0871-8

[20] Ahn, K. B., Baik, J. E., Yun, C-H., \& Han, S. H. (2018). Lipoteichoic acid inhibits Staphylococcus aureus biofilm formation. Frontiers In Microbiology, 9, 327. doi: 10.3389/fmicb.2018.00327

[21] Spinler, J. K., Auchtung, J., Brown, A., Boonma, P., Oezguen, N. Ross, C. L., et al. (2017). Next-generation probiotics targeting Clostridium difficile through precursor-directed antimicrobial biosynthesis. Infection And Immunity, 85(10). doi: 10.1128/iai.00303-17 